\title{
The Innovation of South Sumatera Traditional Batik E-Commerce Applications
}

\author{
Ayu Chotibah ${ }^{1, *}$ Bainil Yulina ${ }^{1}$ Desi Apriyanty ${ }^{1}$ Evada Dewata ${ }^{1}$ Pridson \\ Mandiangan ${ }^{1}$
}

\author{
${ }^{I}$ State Polytechnic of Sriwijaya \\ *Corresponding author. Email: ayuchotibah24@gmail.com
}

\begin{abstract}
This study aims to help develop the sale of various batik with the characteristics of the South Sumatra region by using an information technology (E-Commerce) approach. The distribution of batik sales can be done to help increase the quantity of sales which will result in the output of the Palembang traditional batik E-commerce application. This research will also result Haki certificate outputs, articles that are ready to be published and teaching materials that can be applied to entrepreneurship courses. This study involved 4 partners who were used as objects for data collection, namely the owners of traditional Batik SMEs in South Sumatra. The research methodology used in this study is descriptive analysis method, namely the method by collecting, explaining, analyzing the data obtained and exploring problems that may exist, in the hope of obtaining new knowledge as policy information.
\end{abstract}

Keywords: E-Commerce, Traditional batik, marketing.

\section{INTRODUCTION}

The batik industry is one sector that is prioritized for development by the Ministry of Industry (Kemenperin) because it is considered to have great leverage in boosting national economic growth. This is reflected in the contribution to foreign exchange through export achievements for the January-July 2020 period of USD 21.54 million, an increase compared to the first semester of 2019 of 17.99 million. A quite unique phenomenon, because the export market can increase during the Covid19 pandemic (Jakarta, Investor.id). The main markets for Indonesian batik exports include Japan, the United States, and Europe. Seeing this potential, it is an opportunity to open new markets in the global arena. This is believed to be able to help revitalize the performance of the national batik industry in the midst of the pandemic impact while at the same time introducing a variety of Indonesian batik.

Indonesian Batik is considered to have various comparative and competitive advantages in the domestic and international markets and has succeeded in becoming the market leader in the world batik market. This is a great opportunity for the Indonesian batik industry to continue to expand its market access. The development of batik in Indonesia peaked on October 2, 2009, when UNISCO established Batik Indonesia as the Masterpice of the Oral and Intangible Heritage of Humanity, which is an international recognition that Indonesian batik is a part of the wealth of human civilization. In fact, in the era of the industrial revolution 4.0, we all must be able to create advanced technology that can make the domestic batik industry more competitive. It is because the batik industry is part of a sub-sector of the textile and clothing industry, which is one of the mainstays in the implementation of the Making Indonesia 4.0 roadmap. The batik industry is expected to be able to adapt to new habits or changes by thinking creatively and innovatively through the use of technology and optimizing existing resources, so that it can continue to move and contribute positively to national economic recovery. The Ministry of Industry (Kemenperin) noted that the value of exports in the January-July 2020 period reached US\$ 21.54 million, up 19.73 percent compared to the same period in 2019 which was US\$ 17.99 million. According to data from the Ministry of Industry (Kemenperin), the domestic good industry has reached 47.00 businesses, spread across 101 centers, and employs more than 200,000 people. This industry has also played a major role in contributing to the country's foreign exchange.

Batik is one of Indonesia's original cultures that has its own charm for the community. Many people think that batik is only known and made in Java island, but the fact is that in areas outside Java there are also batik that are 
characteristic of each region. One of them is on the Sumatra island, especially batik in the district/city in South Sumatra province as one of the cultural heritages of the community. South Sumatra province is one of the provinces in Indonesia which is in the southern part of the Sumatera island, also known as Bumi Sriwijaya. Administratively, South Sumatra Province has 13 (thirteen) Regency Governments and 4 (four) City Governments. Each district and city has a local product in the form of batik which is the hallmark of the area itself. Each district/city has batik with different motifs, which makes batik a product of local wisdom such as jupri batik from Palembang, duren batik from Lubuklinggau, gambo batik from Banyuasin, and pusake batik from Musi Banyuasin. This batik has various motifs and patterns. However, the existence of district/city batik in South Sumatra has not been widely known by the community, both from South Sumatra itself and outside South Sumatra, people are more familiar with batik from the Java island. This is because the promotion and socialization of South Sumatran batik is still very limited and marketing channels that have not yet expanded and only limited to their respective regions and have not been nationalized. This condition causes South Sumatran batik to be less known to the wider community in Indonesia, which also has an impact on batik makers who stop produce and will have an impact to the economy decline in business in the district/city area. With the development of technology today, it is very potential to make it easier to run a technology-based business, one of them is by designing a website. The website was chosen as a marketing target because of its easy access and easy to use by buyers. In this study, the author aims to help develop sales of various batik with the characteristics of the South Sumatra region by using an E-Commerce information technology approach to increase the competitiveness of SMEs, especially the sale of batik in the South Sumatra region by giving the title: The Innovation of South Sumatera Traditional Batik Ecommerce Applications. Based on this background, the formulation of the problem is how to develop an E-

Commerce Application for sales transactions of traditional Batik of South Sumatra region which is applied to help increase the marketing of batik from the regions in South Sumatra.

\section{The Objectives}

The existence of the Palembang traditional Batik ECommerce Application Program aims to:

1. For Researchers,

a. Assist/provide convenience to facilitate monitoring the number of batik cloth and batik clothes sold,

b. Providing convenience to customers or buyers about price information for batik cloth and batik clothes c. Knowing the advantages and disadvantages of the application used

d. Knowing how big the influence of batik sales with the construction of this application.

2. For SMEs Owners of traditional batik typical of the region in South Sumatra, can be helped in marketing the batik produced in the region.

\section{LITERATURE REVIEW}

\subsection{Information Technology Approach}

Sorensen (2012) said that the information technology approach is widely used by businesses due to boosting business sales to the maximum. In general, the role of IT is starting to be seen and used, especially in terms of encouraging marketing strategies, one of which is the website (Gelrandy, 2016). With information technology, information can be obtained easily. Information technology has many services and features provided to support the information needs to its users. Regarding business, the other side of the convenience offered by information technology is that it brings buyers and sellers closer together, does not require large investment costs, easy to work with and lastly, IT provides better quality of service tools than conventional methods. Several forms of information technology that can be used to support business activities are websites, CRM. RFID, newsletters, tracking systems, QR-codes that can provide convenience for business processes, both from the customer and operator side (Nurkamid, 2014).

\subsection{The Definition of E-Commerce}

According to the results of previous research conducted by Imam Rivai (2016), Informatics Study Program, University of Surakarta with a journal entitled Online Store Applications (E-Commerce) Based on PHP and MYSQL, discussing how to deal with problems in the marketing field, the company already has a website but still do not have an online store, so when marketing their products the company is less broad in scope, this causes the income earned by the company to be less than optimal. An online store application (e-commerce) is the solution to this problem, this application uses the PHP programming language and MySQL database. This application is made using the waterfall method, in that method there are other stages, while for the research it uses experimental methods and quantitative approaches to test the level of acceptance of application users. Based on black box testing conducted by the admin and testing the level of acceptance of prospective users, it is done by asking respondents to try the system created and then filling out the questionnaire provided, it can be concluded that this application is running well.

E-commerce is one of the advantages of the Internet. There are several names for E-Commerce, which are 
electronic-commerce (e-com) and Immerce, which basically all of the above terms have the same meaning. These terms mean buying or selling electronically and this activity is carried out on the Internet network.

\subsection{Micro, Small, and Medium Enterprises (MSMES)}

Based on Law No. 20 of 2008 regarding MSMEs: Micro-firms are efficient agencies owned through people and/or man or woman commercial enterprise entities that meet the standards for micro-firms as stipulated withinside the law. Small Business is a stand-on my own efficient financial commercial enterprise done through people or commercial enterprise entities that aren't subsidiaries or now no longer branches of organizations which might be owned, controlled, or emerge as a part, both at once or not directly with small agencies or big agencies that meet the commercial enterprise standards. small as mentioned withinside the law. the standards used to outline MSMEs as said in Article 6 are internet well worth or asset fee except land and homes for commercial enterprise premises, or annual income proceeds. With the subsequent standards.

\subsection{The Definition of Information and Information System}

According to Romney and Steinbart (2015:4) "Information is data that has been managed and processed to give meaning and improve the decisionmaking process". According to Krismiaji (2015:14) "Information is data that has been organized, and has uses and benefits". Based on the two definitions described above, it can be concluded that the notion of information is a collection of data that is managed and has its uses and benefits in decision making.

Meanwhile, according to Agus Irawan, et al (2016: 8) "Information systems are systems that are arranged systematically and regularly from information flow networks that connect every part of a system, thus enabling communication between sections or functional units". The understanding of information systems according to Krismiaji (2015:16).

\subsection{Data Flow Diagram (DFD) dan Flowchart}

Kristanto (2018:61) states that DFD is a logical model that describes things that occur during data processing, starting from the origin and destination of the data, where the data is stored, the source of the process that produces the data to the interactions and processes that occur in the data. There are 2 basic DFD techniques that are commonly used, namely Gane/Sarson and Yourdon/De Marco.

According to Sitorus (2015:14), "Flowcharts describe the logical sequence of a problem-solving procedure, so that flowcharts are problem-solving steps written in certain symbols.

\section{RESEARCH METHOD}

\subsection{Implementation Stages}

The stages of research implementation start from collecting related data, designing applications, making ecommerce applications, testing applications, evaluating, and the last is preparing reports.

\subsection{Research Design}

The research methodology used in this study is descriptive analysis method, namely the method by collecting, explaining, analyzing the data obtained and exploring problems that may exist, in the hope of obtaining new knowledge as policy information. According to Utami and Khasanah, SDLC or regularly referred to as the System Development Life Cycle is the manner of growing or converting a software program gadget through the usage of the fashions and methodologies. utilized by human beings to broaden preceding software program systems (primarily based totally on excellent practices or strategies utilized by human beings). nicely tested). The method used in the development of this system uses the waterfall SDLC (Software Development Life Cycle) model. This method is often known as a linear sequential model (Sequential Linear) or classical life cycle (Classic Life Cycle) which is divided into 5 stages, namely: 1) Analysis of system requirements; 2) Design; 3) Code Generation; 4) Testing; and 5) Support.

\subsection{Place and Time of research}

In accordance with the title chosen, the locations that become the object of research are 4 owners of traditional South Sumatran Batik SMEs within a period of 6 months

\subsection{Research Object and Research Result}

Partners who are used as objects of data collection that are the object of research are the owners of traditional batik SMEs in South Sumatra, which are listed in the table below:

Table 1. Traditional Batik in South Sumatra (Partners)

\begin{tabular}{|l|l|l|l|}
\hline No. & Origin & Partner Name & Partner Location \\
\hline 1. & $\begin{array}{l}\text { Palembang } \\
\text { (Batik Jupri) }\end{array}$ & $\begin{array}{l}\text { Griya Tuan } \\
\text { Kentang }\end{array}$ & $\begin{array}{l}\text { Jln.Aiptu A. Wahab } \\
\text { Kec.Seb Ulu 1 } \\
\text { Palembang }\end{array}$ \\
\hline 2. & $\begin{array}{l}\text { Lubuk } \\
\text { Linggau } \\
\text { (Batik Duren) }\end{array}$ & $\begin{array}{l}\text { Rumah } \\
\text { Songket dan } \\
\text { batik Linggau }\end{array}$ & $\begin{array}{l}\text { Jalan Lintas Sumatera, } \\
\text { Kel Kenanga Lubuk } \\
\text { Linggau }\end{array}$ \\
\hline 3. & $\begin{array}{l}\text { Kab. Musi } \\
\text { Banyuasin } \\
\text { (Batik }\end{array}$ & $\begin{array}{l}\text { Rumah Batik } \\
\text { (Deskranasda) }\end{array}$ & $\begin{array}{l}\text { Desa Babat, Kab. } \\
\text { Muba }\end{array}$ \\
\hline
\end{tabular}




\begin{tabular}{|l|l|l|l|}
\hline & Gambo) & & \\
\hline 4. & $\begin{array}{l}\text { Kab. Banyuasin } \\
\text { (Batik Pusake) }\end{array}$ & $\begin{array}{l}\text { Rumah } \\
\text { Sentral batik }\end{array}$ & $\begin{array}{l}\text { Desa Mulya Sari Kec. } \\
\text { TanjungLago } \\
\text { Banyuasin }\end{array}$ \\
\hline
\end{tabular}

Source: Results of data processing to MSMEs

\section{RESULT AND DISCUSSION}

\subsection{Result}

The result of the research is a website-based ecommerce, namely Sumbatiksel. On the website, there are several menus that can be accessed, namely the registration menu and the purchasing menu. Here is the start menu display at e-commerce:
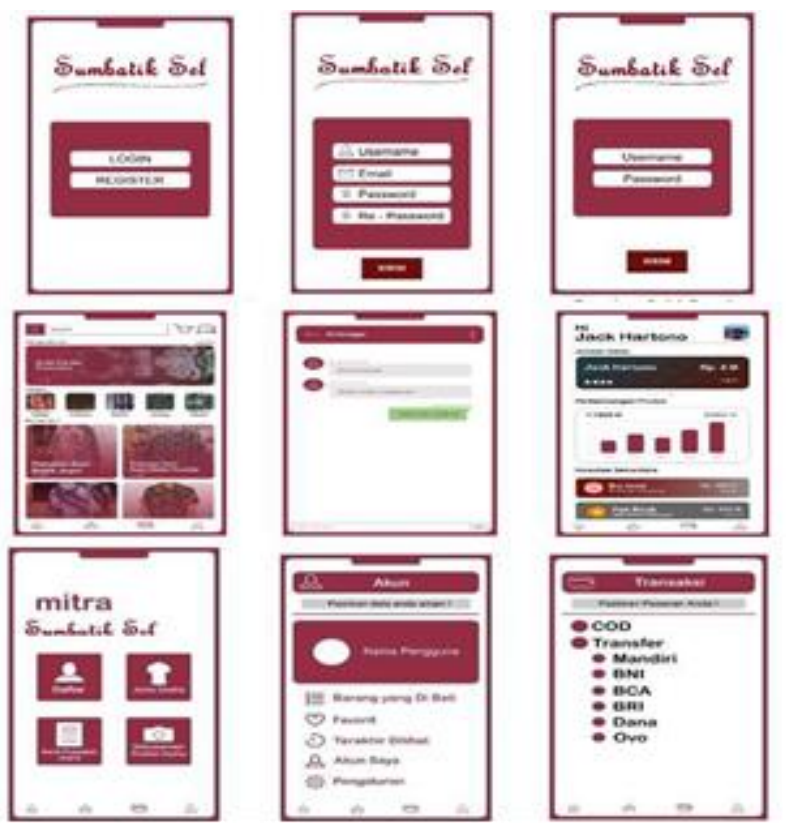

Figure 1 Start menu display of e-commerce

\subsubsection{Registration Menu}

This is the following process that prospective partners must go through if they want to register their business on the Sumbatiksel e-commerce website:

1. Prospective partners must register first to become partners.

2. Prospective partners register into the system.

3. After successful registration, the potential partner will receive an access code and can login to the system as a partner.

4. If the registration is rejected, the prospective partner will receive a notification that the registration was rejected.

5. The system will validate the data entered by the partner when logging in.
6. If the login is successful, partners will be directed to the main page (dashboard) and partners can input product data.

7. If the login fails, the admin will be returned to the login page and asked to login again.

8. If product data is received, partners will receive a notification that the product is received.

9. If the product data is rejected, partners will receive a notification that the product is rejected.

10. Admin logs in to get access rights as admin.

11. The system will validate the data entered by the admin when logging in.

12. If the login is successful, the admin will be directed to the main admin page (dashboard).

13. If the login fails, the admin will be returned to the login page and asked to login again.

14. Admin will confirm the registration made by potential partners.

15. If the registration is accepted, the admin will send the access code to the potential partner.

16. If the registration is rejected, the admin will send a notification to the partner that the registration was rejected.

17. Next, the admin will confirm the product data inputted by potential partners.

18. If the product data is received, the admin will send a notification to the partner that the product is received.

19. If the product data is rejected, the admin will send a notification to the partner that the product is rejected.

Here is the registration menu display at e- commerce:.

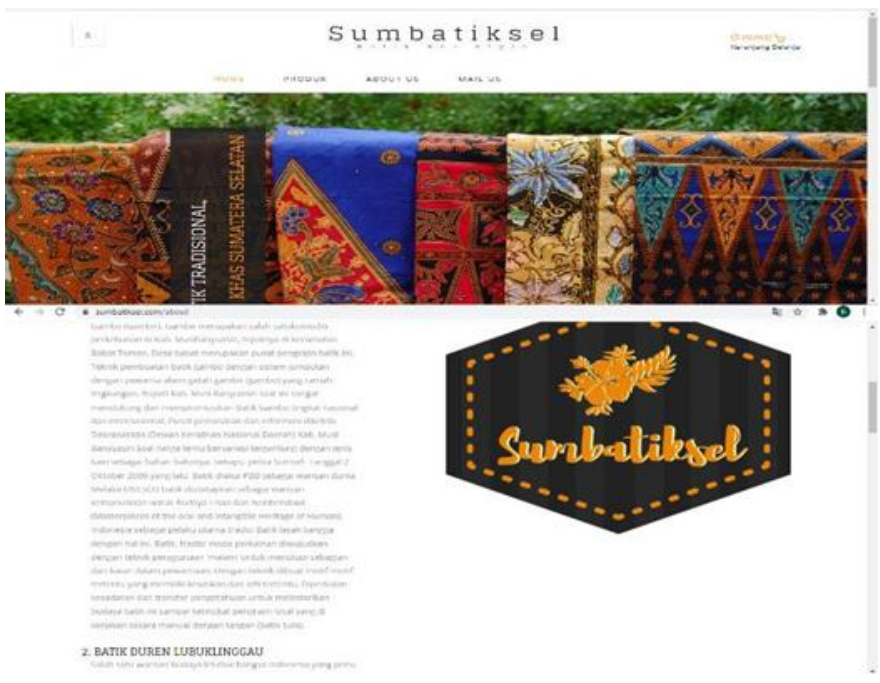

Figure 2 Registration menu display 


\subsubsection{Purchasing Menu}

This is the following process that prospective buyers must go through if they want to buy products on the Sumbatiksel e-commerce website:

1. Users who want to make purchases must be registered as customers.

2. The user registers into the system.

3. After successful registration, the user can log into the system as a customer.

4. The system will validate the data entered by the user when logging in.

5. If the login is successful, the user will be redirected to the main page.

6. If the login fails, the user will be returned to the login page and asked to login again.

7. Customers can choose the product they want to buy, then place an order by filling in purchase data such as address, telephone number, and others.

8. Customers make payments through the system.

9. Partners log in to get access rights as partners.

10. The system will validate the data entered by the partner when logging in.

11. If the login is successful, the partner will be directed to the partner's main page (dashboard).

12. If the login fails, the partner will be returned to the login page and asked to login again.

13. Partners will receive data on orders made by customers.

14. Partner will confirm whether the order will be continued or cancelled.

15. If the order is canceled the partner must refund the customer and the customer will get a refund notification.

16. If the order is continued, the partner will confirm the process of packaging the goods.

17. Customers will get notification of the status of the packaging of the goods.

18. Partner will confirm the delivery of goods.

19. Customers will receive notification of the delivery status of the goods.

20. If the goods have been received by the customer, the customer must confirm through the system that the order has been received.

21. Partners will receive notification that the product has been received.

22. Admin logs in to get access rights as admin.
23. The system will validate the data entered by the admin when logging in.

24. If the login is successful, the admin will be directed to the main admin page (dashboard).

25. If the login fails, the admin will be returned to the login page and asked to login again.

26. Admin can see a list of orders that occur between partners and customers.

27. Admin will also get notification in case of cancellation of orders made by partners.

28. Admin will get reports on payments, packaging, shipping, and products that have been received as evaluation material and improve the admin control function of all activities that take place in the system.

Here is the purchasing menu display at e-commerce:

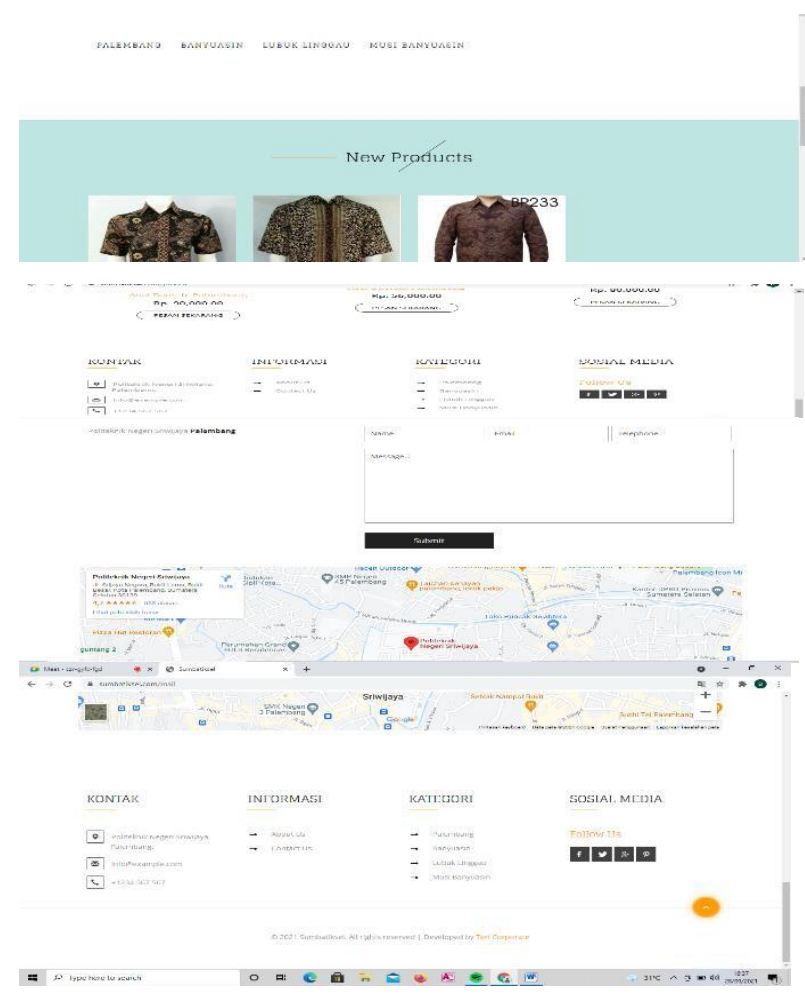

Figure 3 Purchasing menu display

\subsection{Discussion}

According to Said Ilham Nur Efendy's research (2018), University 17 August 1945 Surabaya, in his journal entitled E-Commerce Applications for WebBased Product Sales and Ordering on CV. Cakcuk Surabaya, Learn how to create more effective and efficient information system applications. This allows you to extend and accelerate your promotional and marketing processes and require information media to communicate efficiently with your customers. Excludes resumes. Cakcuk Surabaya introduces new innovations in the sale of clothing and accessories using a web-based 
e-commerce system. The method used in system development is to use the Unified Modeling Language (UML) tool as the modeling language. The results of this survey create a website-based marketing medium with an e-commerce system for resumes. Cakcuk Surabaya so that the available communication options are more efficient for customers.

Utilizing e-commerce which is often called electronic commerce makes batik micro, small and medium enterprises in South Sumatra must work hard. According to Turban (2012) e-commerce is the process of buying, selling, sending, or exchanging products and services and information through computer networks, most of which are the internet. Business people object to online business but gradually they must be willing to take risks to go directly to the virtual world (online). In addition, research by Aisyah and Daulah mentions an increase in competitiveness with network technology or what we often call the internet. This study states that every small business needs internet to develop its competitiveness.

The presence of e-commerce websites can be very helpful in making it easier for shoppers to buy batik sold in stores over the Internet. This website allows sellers to easily promote a wider range of products. Furthermore, to make this information system work properly, it is necessary to have a strong system security and develop to a more professional direction to be able to provide good information. In addition, it is also necessary to do regular data backups to prepare data backups if the data on the web server is damaged or lost. On the web security side, the admin should monitor it regularly, so the unwanted things will never happen. To improve performance and develop existing applications, it is better in terms of the appearance of the web page to be further improved so that it will be more optimal in terms of the interface, planned and routine maintenance of hardware and software.

\section{CONCLUSION}

Based on the descriptions that the authors have described previously, the authors can draw several conclusions, namely the existence of this website can improve service and quality by following technological developments. Assist in the quality of delivering information needed by visitors to the Sumbatiksel website. Product marketing becomes easier so that it expands the reach of consumers. Make it easier for consumers to find information about the products they want to buy and the products that are available. Streamline the time in making reports so you don't have to spend a long time in making reports. Make it easy for consumers to do shopping without being limited by space and time.

\section{REFERENCES}

[1] Agus, I., Hasna, A., \& Pahlevi, R. 2016. Sistem Informasi Perdagangan Pada PT Yoltan Sari Menggunakan PHP Berbasis Web: Jurnal Positif, Jakarta.

[2] Apriyanto ,2020, Perancangan Aplikasi Web Penjualan Pakaian Muslim, Jakarta, Jurnal Universitas Bina Sarana Informatika

[3] Imam Rivai, 2016, Surakarta, Aplikasi Toko Online (E-Commerce) Berbasis PHP dan MYSQL, Jurnal, Program Studi Informatika, Universitas Surakarta

[4] Krismiaji. 2015. Sistem Informasi Akuntansi. Yogyakarta: Sekolah Tinggi Manajemen YKPN.

[5] Kristanto, Andri, 2018, Perancangan Sistem Informasi dan Aplikasi, Edisi Revisi, Yogyakarta. Penerbit Gava Media.

[6] Masitah, 2018, E-Commerce Penjualan Pakaian Pada Lapak Mariati Berbasis Web, Kapuas, Jurnal, Program Studi Sistem Informasi, Fakultas Teknik dan Ilmu Komputer Universitas Islam Indragiri

[7] Nurkamid, M. \& S. 2014. Teknologi Informasi Website dan QR-Barcode untuk Usaha Mikro Kecil Menengah (UMKM) Bordir di Desa Peganjaran Kudus. Prosiding SNST Unwahas- Semarang.

[8] Romney, M. B., \& Steinbart, P.J. 2015. Sistem Informasi Akuntansi. Edisa Tiga Belas. Cetakan Empat Jakarta: Salemba Empat.

[9] Said Ilham Nur Efendy (2018), Surabaya, Aplikasi E-Commerce Penjualan Dan Pemesanan Produk Berbasis Web Pada Cv. Cakcuk Surabaya, Jurnal, Universitas 17 Agustus 1945

[10] Sitorus, Lamhot, 2015, Algorithma dan Pemerograman, Yogyakarta, Penerbit Andi Offset.

[11] Undang-undang Nomor 20 Tahun 2008 Tentang Usaha Mikro Kecil Dan Menengah

[12] Yulina, Bainil, 2019, Pengaruh Kesiapan Modal Dan Pemanfaatan E-Commerce 